\title{
Negotiating Trade: Merchant Manuals and Cross-Cultural Exchange in the Medieval Mediterranean
}

\author{
Joseph F. Stanley \\ Simmons College
}

\begin{abstract}
:
This essay explores Italian mercantile perceptions of the non-western Mediterranean world during the late Middle Ages. In particular, it analyzes the corpus of merchant manuals known as pratiche della mercatura and argues that the intercultural and cross-confessional material included in these handbooks were vital components that helped facilitate trade across ethno-religious frontiers in the Arab-Turkic regions. This paper opens with an examination of the "traditional" manual genre, with particular emphasis on Francesco Pegolotti's Libro di divisamenti di paesi (c. 1310-40). Pegolotti and other pratiche compilers proffered practical counsel on linguistic exchange, local folklore and customs, and resourceful intermediaries (dragomans) that could accommodate cultural assimilation for the trader abroad. The remainder of the essay builds on the fruitful historiographical shifts of recent years and identifies two additional manuals: Leonardo Frescobaldi's Viaggio in Egitto (c. 1390) and Goro Dati's Sfera (c. 1435). These texts, cascaded to a wide merchant audience, include striking language on the common theological underpinnings of Islam, Judaism, and Christianity. These two authors, and specifically Dati, also highlight the complex character of the Italian merchant and reveal that economic self-interest helped construct common ground across major barriers of faith in the medieval Mediterranean.
\end{abstract}

\section{Introduction}

A half-century ago British novelist Lawrence Durrell aptly quipped, "the Mediterranean is an absurdly small sea; the length and greatness of its history makes us dream it larger than it is" (Durrell, 1961: 18). As the liquid connector of three disparate, ethnically diverse continents, the Mediterranean continues to dominate public discourse today, particularly in the sphere of geopolitics with ISIS, the refugee crises, and the horrific transgressions in Paris, Brussels, and Barcelona comprising the bulk of international headlines. Indeed, this region and its complex history has provided much fodder in U.S. political debate with former presidential candidate Carly Fiorina affirming she would employ her medieval baccalaureate degree from Stanford University to combat ISIS and prevent a return to the Middle Ages - thereby invoking the Crusades and painting a somewhat parochial picture of "Christians versus Muslims" (Fiorina, 2015). This picture, however blurred, has been etched into the collective consciousness of many of us in the twenty-first century, partly because of the way in which we consume the Mediterranean's past from a post-9/11 perspective. The increase of trans-Mediterranean mobility following the Commercial Revolution in the eleventh, twelfth, and thirteenth centuries - so the new narrative goes - initiated a permanent state of war and competition between Muslim, Byzantine, and European regional powers over 
control of the Mediterranean's sacred lands and maritime routes (Valérian, 2014: 88-89). I was witness to these shifting attitudes firsthand as an American studying abroad on the banks of the Mediterranean in Italy where my first day of class ominously coincided with September 11, 2001. The collective ethos of sadness, community, and solidarity displayed by my many classmates and colleagues, both American and European, in the immediate aftermath of 9/11 quickly manifested into an increasingly bellicose and insular mentality of "us versus them." The September attacks, it seemed, were no more than a continuation of a continual conflict ensconced in historic tradition.

In the years since 2001, there has been a flood of studies seeking to combat this aforesaid parochialism and highlight the cultural fluidity and porous boundaries that existed between the various ethnic and religious sects that populated the medieval Mediterranean. Building on the trailblazing groundwork laid by Fernand Braudel (1966), the efforts of Peregrine Horden and Nicholas Purcell (2000), Olivia Constable (2003), David Abulafia (2011), and Brian Catlos (2014) to name a few - have convincingly shown the Mediterranean as a fragmented terrain imbued with strands of cultural hybridity. The paragraphs that follow constitute a continuation of this historiographical trend. But rather than focus on the convivencia of al-Andalus and the greater Iberian Peninsula, a topic that has been brilliantly described by an able body of scholars (some of whom have contributed to this collection), this essay explores the intellectual preoccupations of the Italian trader.

Historians have long recognized Italian preponderance in Mediterranean commerce during the late Middle Ages. More recently, studies have greatly enriched our understanding of how crosscultural communication helped foster Italian mercantile relations in foreign, non-European markets (Epstein, 2007). Yet surprisingly, a corpus of material that constitutes a valuable documentary record of the Italian merchant's education and understanding of Islamic and Crimean cultures remains untouched: pratiche della mercatura, or "manuals of commercial practice". These handbooks, widely circulated throughout central and northern Italy, contained vital information pertaining to the merchant's understanding and awareness of Arabic-Turkic cultures and customs outside the realm of commercial affairs. Taking these manuals as its documentary focus, this essay proposes new ways of reading and classifying these texts whilst exploring Italian mercantile conceptions of the nonwestern Mediterranean world. Indeed, the cross-cultural understanding and exchange gleaned from their pages suggest these manuals were imperative tools used by the Italian merchant in negotiating trade with the so-called "Other."

Before delving into the manuals, it is important to understand what defines a merchant handbook and how the genre has evolved in recent historiography. Pratiche della mercatura were manuscript compilations that encompassed a wide variety of practical information for the Italian mercante, or merchant. Composed between the late thirteenth and fifteen century throughout northern Italy, these handbooks comprised important "data about weights and measures, moneys and exchange, commodities and techniques, markets and fairs, customs, transportation, and other details a merchant should keep at hand" (Lopez, 1969: 36). Gian Francesco Pagnini della Ventura first classified the literary category in 1766, where today fourteen manuals (see Table 1) appear in printed form (Ventura, 1967). Replete with statistical figures, these texts have long provided 
economists with crucial data to help illustrate the nuanced complexities of the Mediterranean's diverse economies as well as the financial acumen of the Italian trader (Witthöft, 1987). In more recent years, however, scholars have begun to celebrate the diversity of the handbook genre. Once bound to the rigid financial parameters set by Ventura, historians have found it useful to classify the commercial handbook based on didactic material relevant to a merchant's education. Marco Polo's Devisement du monde "Description of the World" (c. 1298), for example, a work that entirely excludes statistical figures, has been identified as the most famous pratica della mercatura by renowned literary scholar Vittore Branca (Branca, 1986: xiv-xv). Bereft of economic data, Polo's account nevertheless provides important mercantile information in the detailed descriptions of foreign markets and commodities while highlighting the diverse cultures and customs of Persia, India, and the Mongol Empire. Similarly, Benedetto Cotrugli's Libro dell'arte di mercatura "Book of the Art of Trade" (1458) neglects to cascade idiosyncratic details concerning currencies or commodities to its commercial audience. Rather, the Neapolitan merchant and diplomat found it more beneficial to instruct the reader on business ethics and the mechanics of double-entry bookkeeping.

Table 1. Published Pratiche della Mercatura ${ }^{i}$

\begin{tabular}{|l|l|l|l|}
\hline \multicolumn{1}{|c|}{ Title } & City of Origin & \multicolumn{1}{c|}{ Author } & \multicolumn{1}{c|}{ Year } \\
\hline Liber abbaci & Pisa & Leonardo Fibonacci & 1202 \\
\hline Memoria de tucte le mercantile & Pisa & Unknown & c. 1278 \\
\hline Devisement du Monde & Venice & Marco Polo & c. 1298 \\
\hline Codex Cumanicus & Genoa & Unknown & c. 1303 \\
\hline Libro di divisamenti di paesi & Florence & Francesco Pegolotti & c. $1310-40$ \\
\hline Zibaldone da Canal & Venice & Da Canal family & c. $1311-31$ \\
\hline Tarifa zoè noticia & Venice & Unknown & c. 1350 \\
\hline Untitled & Florence & Simone Acciaiuoli & c. $1375-1400$ \\
\hline Untitled & Florence/Prato & Datini Company & c. $1385-86$ \\
\hline Untitled & Florence & Ambrogio de' Rocchi & c. $1394-95$ \\
\hline Manuale di mercatura & Florence & Saminiato de' Ricci & 1396 \\
\hline Libro di gabelle & Florence & Giovanni Uzzano & 1442 \\
\hline $\begin{array}{l}\text { El libro di mercatantie et } \text { usanze } \\
\text { de' paesi }\end{array}$ & Florence & Giorgio Chiarini & 1458 \\
\hline Libro dell'arte di mercatura & Naples & Benedetto Cotrugli & 1458 \\
\hline
\end{tabular}

Francesco Pegolotti's Libro di divisamenti di paesi "Book of Descriptions of Countries" (c. 1310$40)$ is the most complete and perhaps well-known work among the commercial handbook corpus. Pegolotti was a prominent member of the Florentine Bardi banking company at a time when Florence was the leader of international finance. The company maintained branches in Europe's major commercial centers of London, Paris, Avignon, and Bruges and could also boast of satellite branches throughout the Mediterranean including Rhodes, Majorca, Constantinople, and Cyprus (Pegolotti, 1936: xv-xxvi). Pegolotti, in fact, spent several years in Famagusta on behalf of the Bardi where he most likely composed a bulk of the Libro. This Cypriot city was a nexus of commerce that brought to its port traders and diplomats from all corners of the Mediterranean and surely had profound impacts on the composition of the handbook. Pegolotti's lengthy text (the printed edition runs just under four hundred pages) provides formulaic listings of foreign currencies, commodities, 
and measures from over fifty markets around Europe and the Mediterranean basin. Future pratica authors in both Tuscany and the Veneto would rely heavily on the Libro's formulaic framework, even copying some data verbatim, suggesting that Pegolotti's manual had a significant merchant audience (Stanley, 2011: 25). The vast majority of entries found in the Libro collates and translates commercial metrics and standards employed throughout the Mediterranean's diverse centers of commerce. In comparing the measurements of Acre of Syria with Constantinople, for example, a typical entry reads:

1 cantar of Acre equals 438 heavy pounds in Constantinople; 100 heavy pounds in Constantinople are equivalent to 140 light pounds in Constantinople; 10 mene in Acre make $15 \frac{1}{2}$ heavy pounds in Constantinople. ${ }^{\text {ii }}$

This rather monotonous record typifies a preponderance of the Libro's entries and also underlines the Italian merchant's penchant for precision and accurate record keeping.

Yet, interspersed within these enumerating chapters, the reader is furnished with cultural guides as well. The Libro, for example, provides the aspiring merchant with an extensive lexicon of foreign languages entitled Dichiarigioni (Pegolotti, 1936: 14-19). This section translates a host of commercial and nautical terms from Pegolotti's native Tuscan Italian into twenty-two dialects spoken throughout the Mediterranean. Here, the reader becomes familiar with phraseologies in Arabic, Persian, Armenian, Cuman, even Trapezuntine - the local vernacular of Trebizond. The striking similarities found in Pegolotti's translations (doana, for instance, denotes "tariff" in the Arabic, Sicilian, Neapolitan, and Pugliese dialects) immediately conjure up the lingua franca, the amalgamation of Arabic and Romance vernaculars that served as a "language of convenience" in the pre-modern Mediterranean. According to Karla Mallette, this communicative tool - constantly shifting to meet local dialectic exigencies - served to transcend the linguistic divisions that stymied communication and functioned as a strong vehicle of acculturation (Mallette, 2014: 332).

Pegolotti's guide on practical philology also generates particular resonance with the contemporary Genoese Codex Cumanicus (c. 1303), a crude Latin-Persian-Cuman manual employed for mercantile and missionary purposes. Trade between Italian merchants and Crimean traders along the Black Sea had developed in the thirteenth century and the years around 1300 saw robust patterns of commerce blossom between these two groups (Finch, 2008: 79-80). The first half of the Codex includes lengthy lists of commodities and other commercial terms in addition to phonetic instructions on how to conjugate verbs employed in commercial transactions like "to value" and "to spend". Curiously, the first half also incorporates an eclectic breadth of quasi-mercantile, quotidian vocabulary: weather formations, humours of the body, familial terms, how to compliment a foreigner in situ, as well as political offices one might find in Crimea and Persia. The latter half of the Codex was fashioned in the spirit of religious proselytization and, as such, it comprises chapters with a far more spiritual bent. ${ }^{\text {iii }}$ Yet alongside the homiletic Pater Noster and Nicene Creed, we find passages devoted to Cuman riddles and folklore. These passages, taken together with the aforesaid Codex entries, constitute "a common heritage of the Turkic-speaking nations," and, thus, strongly indicate a certain level of cultural competency was transmitted to the reader (Tietze, 1966: xi).

A foundational knowledge of the Cuman and Persian languages was deemed essential for the merchant desiring to trade east of the Levant. Pegolotti's Libro, for example, devotes a chapter to the 
long journey to Cathay (Avisamento del viaggio del Gattaio) where he takes the mercante through the heart of Cuman-speaking Crimea (Pegolotti, 1936: 21-23). Indeed, it is in these pages that the reader can glean a number of guidelines on cultural assimilation. Pegolotti advises the reader to grow a long beard, for instance, during this voyage and when conducting trade in order to adhere to the aesthetic norms of the Cumans and Mongols. Thereafter, he encourages the merchant to furnish himself with multiple interpreters and guides who are well versed in the Cuman language. Pegolotti strongly counsels against frugality, implying that a reliable dragoman can yield dividends in securing favorable commercial transactions. This directive, in fact, chimes emphatically with the recent work of $\mathrm{E}$. Natalie Rothman who has convincingly shown diplomatic and mercantile interpreters as resourceful intermediaries of acculturation in the early modern Mediterranean (Rothman, 2011). Pegolotti further advises the merchant on foreign culture in his brief commentary on eastern politics. We read that transfers of lordly power on the road between Crimea and Cathay can lead to bouts of disorder and sometimes violence against "Franks." The European, Pegolotti warns, should practice vigilance during these transitional periods and refrain from travel and conducting trade with Cumans.

Curiously, this chapter also acknowledges that an accompanying female will garner greater respect for the traveling trader: "if the merchant wishes to take along from Tana [to Cathay] any woman with him ... he will be regarded as a man of higher condition than if he does not take one." ${ }^{\text {,iv }}$ In this context, the author is undoubtedly referring to female slaves, who constituted a significant part of the thriving and tragic Eurasian slave trade. Pegolotti's admonition to bring an accompanying slave may have been purely transactional. Female slaves, and young ones at that, were seen as propitious investments throughout Crimea, including Tana, where it was commonplace to find women and children destined for domestic servitude. But the accompaniment of a female companion was likely viewed as a distinction of social status. Sources indicate that the elite stock of medieval and early modern Crimea had cultivated deep appreciations for beauty and exoticism and that young slaves were frequently exploited for their sexual service (Dash, 2015). Writing his travelogue (Seyâhatnâme) some three centuries after Pegolotti (1664), Ottoman author Evliya Çelebi recorded a select number of Cuman phrases that he surmised would be useful for travelers visiting the Black Sea's northern coast. Significantly, among the vernacular expressions he included was "Bring a girl" (Çelebi, 1834: 58). Pegolotti's commentary on this particular topic is brief, but one could argue that by adhering to this counsel the merchant could further legitimize and homogenize himself in the foreign milieu of the Cuman-Kipchak state.

The traditional handbook corpus, thus, can yield valuable material as it relates to mercantile awareness of foreign cultures around the Mediterranean and beyond. Rich with comparative metrology of wares and tares, the pratiche also provided the merchant audience with practical instructions on linguistic exchange, local folklore and customs, and other means of culturally assimilating as a trader abroad. And as we shall see, mercantile counsel could also include engaging fodder on confessional pluralism.

\section{$* * *$}

During a fortuitous visit to Cornell University's Rare Manuscript Library some years ago, I came across a fifteenth-century Florentine compendium of manuscripts, $M s$ 355. The volume is bound in its original wooden boards and leather back with the inscription Sapienza, or Knowledge, 
emblazoned on the cover to establish its original purpose as an edifying text - further bolstered by the plethora of marginal notes. The codex includes a medley of didactic material on Christian ethics including the Dieci Commandamenti "Ten Commandments," the Dodici Artichole della Fede "Twelve Articles of Faith", and the Sette Sacramenti "Seven Sacraments". But over half of the manuscript's sixty-eight leaves are reserved for the works of two Florentine merchants. The first is the pedagogical poem entitled the Sfera "Sphere" (c. 1435), composed by the silk trader Gregorio - or Goro - Dati. The Sfera was one of the most copied works of Quattrocento Florence and, until recently, has largely been overlooked as a merchant text on account of an authorship dispute that previously attributed the work to Dati's brother Leonardo, the Master General of the Dominican Order (Bertolini, 1982). Handsome profits, pirate raids, and bankruptcy paint a volatile picture of Goro's tumultuous mercantile career that saw him travel the Mediterranean extensively, particularly around Spain (Dati, 1968). The poem is divided into four books, each comprising thirty-six stanzas set in ottava rima, with a rhyming scheme of a-b-a-b-a-b-c-c. The text opens with a broad survey of the geocentric cosmos and, as the reader advances, the Sfera narrows its focus on the terrestrial sphere. The latter three books, in fact, examine a variety of material that evoke the subject matter found in the Codex Cumanicus: weather patterns, human physiology, navigational tools, and a geographical tour of commercial and biblical cities throughout North Africa and the Levant. The second merchant text found in Ms 355 is the Viaggio in Egitto e in Terra Santa "Visit to Egypt and the Holy Land", written by the banker Leonardo Frescobaldi following his thirteen month voyage to the Holy Land (c. 1390). Frescobaldi's account chronicles his travels between Alexandria and Beirut where he and an entourage of twelve Tuscans visited no less than twenty locales that held biblical, apocryphal, and commercial significance. The Viaggio is part reflective in its sense of wonder in all things foreign and part didactic in its eclectic descriptions of commercial goods, Arabic customs and history, local weather patterns, and theology - both Christian and Islamic.

Shortly after encountering $M s$ 355, a visit to the Biblioteca Riccardiana in Florence serendipitously put me in front of the fifteenth-century compendium known as Ricc. 818. Like $M s$ 355, the Riccardiana volume's first half features a veritable zibaldone, or medley, of instructive material on rudimentary medicine, proverbs, Christian prayers, and historical notes. And significantly, the manuscript's second half, similar to Ms 355, comprises Dati's Sfera and Frescobaldi's Viaggio. The wide-ranging subject matters and expository inclusions found in both compendiums strongly suggest they were employed for didactic purposes and studied by those engaged in mercantile affairs. It is unlikely that these compendiums, particularly the Sfera and Viaggio, were part of an organized curriculum. We know, for example, that aspiring tradesmen typically pursued a fulltime apprenticeship in their early teens following the successful completion of the abbaco, or "arithmetic," school (Grendler, 1989: 306-329). Rather, these texts would have been of interest to the merchant autodidact who harbored humanist interests. The Quattrocento banker, historian, and indefatigable traveler Benedetto Dei, for example, cited the Sfera as an indispensable resource he employed during his commercial voyages to the Levant (Segatto, 1983: 176). ${ }^{\mathrm{v}}$ And Christian Bec reminds us that an ethos of "merchant humanism" developed in the early years of the fifteenthcentury in Florence thanks, in part, to the cross-pollination of commerce, politics, and the arts. In efforts to satisfy their literary and philosophical tastes, Florentine traders invested in robust libraries, maintained close relations with humanist statesmen, and perfected their capabilities in a range of subjects including linguistics, geography, and jurisprudence. (Bec, 1967: 437-446). 
Based on these interpretations, and building on the fruitful historiographical shifts of recent years surrounding the manual genre as discussed above, it would be of value to include Dati's Sfera and Frescobaldi's Viaggio in the pratica corpus. Both texts were written by mercanti, included in codex compilations for mercanti, and comprise an assortment of material that satisfied the commercial and intellectual interests of the Quattrocento trader. And while the Sfera and Viaggio may not incorporate comparative metrology, a hallmark feature of the "traditional" genre espoused by Ventura and economic historians, their explicative nature strongly resonate with the material found in the more recently classified pratiche of Marco Polo and Benedetto Cotrugli. Moreover, the accounts of Dati and Frescobaldi provide valuable details regarding the merchant's understanding of Saracen culture.

Frescobaldi's Viaggio is most explicit in this regard. As already noted, the Viaggio records the chronological voyage of thirteen Tuscans touring commercial and pilgrimage sites between Egypt and Lebanon. Whilst in the Levant, for example, the text chronicles the visits to Christian destinations found on the Holy Circuit where Frescobaldi provides lengthy biblical commentaries concerning Gaza, Mount Sinai, and Nazareth among many other religious locales (Frescobaldi, 1948: 57-88). Throughout these entries, Frescobaldi proffers commercial guidance as well. He favorably compares Alexandria to his native Florence as a nexus of great trade, for instance, and we discover that the Egyptian port specializes in the sale of spices, sugar, and silk (ibid.: 41). The reader discerns that exceptional merchant jewelers reside near the Sultan's castle in Cairo who specialize in emerald and turquoise stones. In Egypt, the merchant should be prepared to make all commercial transactions using the local currency, including the bezant, dirhem, and folari, for which the Viaggio provides conversation rates against the Venetian ducat (ibid.: 47). Frescobaldi even evaluates the livestock and agricultural commodities found in nearby Materia (ibid.: 54). Woven through these accounts, however, it is palpable that Frescobaldi cultivates deep interest in the Saracen way of life. Whilst in Cairo, an "imperial city" rich with "spices and every victual," Frescobaldi illuminates the citizenry's dining habits and culinary culture, marital traditions, and the multi-cultural makeup of the civic militia: "Turks, Tartars, Arabs and some Saracens" alongside "Jews and Christians" (ibid.: 4750). He also discloses the fashion tastes of the Cairenes where Frescobaldi highlights the "noble" significance of the female hijab (ibid: 47).

Of greater interest, however, are the passages devoted to Islamic theology and liturgical rites. The Viaggio, for instance, includes a concise section on the city of Mecca and the sacred importance of the Hajj (86). The reader learns that the Muslim New Year - Mubarram - derives back to the life of Mohammed and lasts one lunar cycle. To pay homage during the Muharram, Muslims fast during daytime and "go to their mosques and to their sanctuaries and to their pardons" and at night "[stand] abroad by the bazaars, [eat] meat and whatever pleases them" and partake in "singing and dancing" (Frescobaldi, 1948: 50). Thereafter, when recording the group's arrival to Palestine, Frescobaldi explains the significance of Ramadan, the Muslim holy month of fasting that he likens to Lent (ibid.: 68). During his stay in Palestine, Frescobaldi also underscores the common theological underpinnings of Judaism, Christianity, and Islam. It was in the "Fields of Damascus" that God bore Adam, "our first father," whom "the Saracens and Jews revere... as we Christians do" (ibid.: 68). He also notes that "the Saracens, the Jews, and all the Christians...have great faith" in the patriarchal figures of Abraham, Isaac, and Jacob (ibid.: 68). Continuing with the theme of religious commonality, the Viaggio offers the merchant audience a remarkably poignant explication of shared Islamic-Christian heritage. 
And know you that the Saracens pay reverence to the Virgin Mary and to St. John the Baptist and to St. Catherine and to all the patriarchs of the Old Testament; and they hold Christ to be, after Mohammed, the greatest prophet, and that he was not born of the corruption of the flesh, but that the breath of God the Father by the mouth of the Angel gave flesh to the Divine Word; and in many things they draw near to our faith (Frescobaldi, 1948: 50).

These statements of commonality, presumptively cascaded to a wide mercantile audience, are striking indeed. But they also smack of the cross-cultural foundations that were necessary to facilitate trans-Mediterranean trade and diplomacy. Steven Epstein suggests that European ambassadors and merchants, primarily from the Italic peninsula, were in the best position to forge relationships that transgressed linguistic, confessional, and ethnic frontiers. In attempts to build relationships with common commercial goals in mind, Christians and Muslims "created a bond whose durability and sincerity might have been initially questionable" (Epstein, 2007: 96). Under these circumstances, economic self-interest transcended barriers of religious affiliation or ethnicity. As a man of commercial affairs, Frescobaldi's counsel on the Muslim faith and the doctrinal values it shares with Christianity can be construed as a vital "area of common ground" to which Epstein refers.

A cursory glance at the Sfera, however, would appear to complicate this interpretation. The poem's third and fourth libri supply a written world map (or medieval mappamundi) and comprehensive portolan of navigational instructions between commercial and biblical cities in North Africa and Asia. The reader, for instance, becomes conversant in how to employ a map, compass rose, and horologe when navigating the high seas and learns the fundamental principles of boat rigging and tacking (Dati, 1865: 27-30). Akin to the Viaggio, Dati highlights the commercial significance of these foreign lands while emphasizing their opulence. Alexandria is heralded as a lucrative port for merchandise that is equipped with fertile lands and abundant crops whereas Cairo is described as a city "[c] he l'abbondanza è quivi cosa vera" ("where opulence is a reality"; Dati, 1865: 37). India is portrayed as bountiful in spices and grain and we learn of the caravans that bring these highly valued commodities to the markets of Damascus and Alexandria (Dati, 1865: 33).

Yet Dati's brief depictions of the inhabitants of these regions, and the faiths to which they subscribe, contrast sharply with Frescobaldi. The Cumans, for example, are described as a people who merely live like "beasts in their laws and in their food." "vi The Sfera also devotes half of one stanza to Islam's holy city of Mecca, which the reader discerns is a populous place "where the cursed Mohamed is buried, in an iron arc." vii Despite Dati's xenophobic and prejudicial misgivings towards Cumans and Muslims, his patterns of thought - construed holistically - still corroborate our earlier findings. In particular, the positive commercial appraisals of these foreign lands, coupled with a transparent bias towards those who populate them, reveal that mercantile perceptions of the "Other" were by no means idealistic or simplistic. Rather, Dati seems to tacitly imply that certain levels of tolerance were needed to negotiate trade in the lucrative cities of Alexandria, Cairo, and Damascus. Put another way, the preoccupations of the mercanti italiani were far more layered, complex, and shrewd than a blatant dislike or unequivocal acceptance of the Saracen or Cuman. During commercial encounters, differences were put aside, tolerance practised, and ethno-religious barriers trumped all in the name of economic self-interest. Indeed, upon taking surveillance of Galilee and the surrounding areas, Frescobaldi - a veritable polyglot by today's standards - records 
that the region "would be taken in hand-to-hand fighting," an obvious reference to the European Christian vision of forcefully re-appropriating the Holy Land from Muslim rule (Frescobaldi, 1948: 83). Frescobaldi's remark, taken together with his tolerant views on the Islamic faith, serves as an important reminder that Mediterranean spaces were multilayered sites that accommodated the continual interchange of pluralism and contestation.

\section{Conclusion}

The purpose of the preceding paragraphs is not to romanticize cross-cultural encounters in the context of the medieval Mediterranean, a slippery slope of which recent historiographical efforts have been accused (Jacoby, 2008). Rather, they are meant to highlight several examples of mercantile attempts at crossing dialectic, religious, and ethnic frontiers by using a documentary corpus far overlooked for its social and intercultural value. Linguistic counsel, an understanding of local folklore, and confessional tolerance were just some of the attributes deemed essential when conducting trade in the foreign, Arab-Cuman lands. And although Goro Dati's prejudicial misgivings seemingly complicate this picture, the Sfera further underscores the complex character of the medieval trader and how commercial self-interest helped construct common ground across major barriers of faith. Here, it is important to reflect that Dati himself conducted a great deal of his commercial affairs in Valencia and Barcelona, two maritime cities inundated with merchants representing the Mediterranean's diverse ethno-religious backgrounds (Dati, 1968). These examples, however, constitute only a fraction of what remains to be explored from pratiche della mercatura and it is my hope that this essay will inspire new modes of investigation.

\section{Works Cited}

Abulafia, David. The Great Sea: A Human History of the Mediterranean. Oxford: Oxford University Press, 2011.

Bec, Christian. Les Marchands Écrivains: Affaires et Humanisme à Florence, 1375-1434. Paris: Mouton, 1967. Print.

Bertolini, Lucia. "Censimento dei manoscritti della Sfera del Dati: i manoscritti della Biblioteca Laurenzia." Annali della Scuola Normale Superiore di Pisa III (1982): 665-705. Print.

Braudel, Fernand. La Méditerranée et le monde méditerranéen à l'époque de Philippe II. Paris: A. Colin, 1966. Print.

Catlos, Brian. Muslims of Medieval Latin Christendom, c. 1050-1614. Cambridge: Cambridge University Press, 2014. Print.

Çelebi, Evliya. Narratives of Travels in Europe, Asia, and Africa, in the Seventeenth Century. Trans. Joseph von Hammer. Vol. 2. London: Oriental Translation Fund of Great Britain and Ireland, 1834. Print.

Constable, Olivia. Housing the Stranger in the Mediterranean World: Lodging, Trade, and Travel in Late Antiquity and the Middle Ages. Cambridge: Cambridge University Press, 2003. Print.

Cotrugli, Benedetto. Il libro dell'arte di mercatura. Ed. Ugo Tucci. Venice: Arsenale, 1990. Print.

Dash, Mike. "Blonde cargoes: Finnish children in the slave markets of medieval Crimea." A Blast from the Past Jan. 2015. Web. 5 June 2016.

Dati, Goro. Il libro segreto. Ed. Carlo Gargiolli. 1869. Bologna: Commissione per i testi di lingue, 1968. Print.

“---. La sfera: libri quattro in ottava rima: scritti nel secolo XIV da F. Leonardo di Stagio Dati. Eds. G.C.

Galetti, E. Narducci. Milan: G. Daelli, 1865."

Durrell, Lawrence. Balthazar. New York: Dutton, 1961. Print.

Epstein, Steven. Purity Lost: Transgressing Boundaries in the Eastern Mediterranean, 1000-1400. Baltimore: Johns Hopkins University Press, 2007. Print. 
Finch, Roger. "Christianity among the Cumans." Surugadai University Studies 35 (2008): 75-96. Print. Fiorina, Carly. "Town Hall Meeting." Windham, NH. 4 Oct. 2015. Speech.

Frescobaldi, Leonardo. Visit to the Holy Places of Egypt, Sinai, Palestine, and Syria in 1384. Ed. and trans. Theophilus Bellorini and Eugene Hoade. Jerusalem: Franciscan Press, 1948. Print.

Grendler, Paul. Schooling in Renaissance Italy: Literacy and Learning, 1300-1600. Baltimore: Johns Hopkins, 1989. Print.

Horden, Peregrine, and Nicholas Purcell. The Corrupting Sea: A Study of Mediterranean History. Oxford: Blackwell, 2000. Print.

Jacoby, David. Review of Purity Lost by Steven Epstein. Baltimore: Johns Hopkins University Press, 2007. American Historical Review October 2008: 1213. Print.

Lopez, Robert. "Stars and Spices: The Earliest Italian Manual of Commercial Practice." Economy, Society, and Government in Medieval Italy: Essays in Memory of Robert L. Reynolds. Eds. David Herlihy, Robert Lopez, Vsevolod Slessarev. Kent: Kent State University Press, 1969. 35-42. Print.

Lopez, Robert, and Irving Raymond. Medieval Trade in the Mediterranean World. New York: Columbia University Press, 1961. Print.

Mallette, Karla. "Lingua Franca." A Companion to Mediterranean History. Eds. Peregrine Horden, Sharon Kinoshita. Chichester: Wiley Blackwell, 2014. 79-90. Print.

Ortega, Stephen. Negotiating Transcultural Relations in the Early Modern Mediterranean: OttomanVenetian Encounters. Farnham: Ashgate, 2014. Print.

Pegolotti, Francesco. La pratica della mercatura. Ed. Allan Evans. Cambridge: The Medieval Academy of America, 1936. Print.

Polo, Marco. Le devisement du monde. Ed. Philippe Ménard. 6 vols. Geneva: Droz, 2001-2009. Print.

Rothman, E. Natalie. Brokering Empire: Trans-Imperial Subjects between Venice and Istanbul. Ithaca: Cornell University Press, 2011. Print.

Segatto, Filiberto. "Un'immagine quattrocentesca del mondo: la Sfera del Dati." Accademia nazionale dei Lincei: Classe di scienze morali, storiche e filologische. 27 (1983): 147-81. Print.

Spufford, Peter. "Late Medieval Merchants' Notebooks: A Project; Their Potential for the History of Banking." Kaufmannsbücher und Handelspraktiken vom Spätmittelalter bis zum beginnenden 20. Jahrhundert. Eds. M. A. Denzel, J. C. Hocquet, H. Witthöft. Stuttgart: Steiner, 2002. 47-62. Print.

Stanley, Joseph. "From Medieval Corporatism to Civic Humanism: Merchant and Guild Cultural in Fourteenth- and Fifteenth-Century Florence.” Diss. SUNY Binghamton, 2011. Print.

Tietze, Andreas. The Koman Riddles and Turkic Folklore. Berkeley: University of California Press, 1966. Print.

Valérian, Dominique. "The Medieval Mediterranean." A Companion to Mediterranean History. Eds. Peregrine Horden, Sharon Kinoshita. Chichester: Wiley Blackwell, 2014. 79-90. Print.

Ventura, Gian Francesco Pagnini della, ed. Della decimal e di varie alter gravezze imposte dal comune di Firenze: della moneta e della mercatura de' Fiorentini fino al secolo XVI. Vol. 3. 1755-1756. Bologna: Forni, 1967. Print.

Witthöft, Harald. "Sizilische Tari - italienische libbra - nordwesteuropäische Mark. Pegolottis 'Pratica della Mercatura' (1310-1340) in neueren Forschungen." Hochfinanz - Wirtschaftsräume Innovationen. Festschrift für Wolfgang von Stromer. Eds. Uwe Bestmann, Franz Irsigler, Jürgen Schneider. Trier: Auenthal, 1987. 421-468. Print.

\footnotetext{
i The table was compiled using the indexes found in Lopez and Raymond (1955: 341-358), Spufford (2002: 49-50), and Stanley (2011: 24-27).

ii "Cantar 1 d'Acri fa in Gostantinopoli libbre 438 grosse. Libbre 100 grosse di Gostantinopoli sono in Gostantinopoli libbre 140 sottili. Mene 10 d'Acri fanno in Gostantinopoli libbre 15 1/2 grosse” (Pegolotti, 1936, 64).

iii Although the Codex Cumanicus included contributions from both commercial and Christian compilers, Roger Finch reminds us the Codex, in its holistic form, was read by a wide merchant audience (Finch, 2008: 80).
} 
iv "E se il mercatante vuole menare dalla Tana niuna femmina con seco, sì puote, e se non la vuole menare non fa forza, ma pure se la menasse sarà tenuto di migliore condizione che se non la menasse, e però se la mena conviene che sappia la lingua cumanesca come il fante" (Pegolotti, 1936: 21-22).

v Filiberto Segatto also claims that the Sfera would have been a popular medium among late medieval artisans, merchants, and pilgrims (Segatto, 1983: 176).

vi "Gente bestiale di legge e di vivande" (Dati, Book 3, Verse 20).

vii "Là dove sta sepulto il maladetto/ In un arca di ferro Maumetto" (3, 29). 